\title{
Spatial distribution of natural enrichments of As, Se, and $U$ in a minerotrophic peatland, Gola di Lago, Canton Ticino, Switzerland
}

\author{
ZAYRE I. GONZÁLEZ A., MICHAEL KRACHLER, ANDRIY K. \\ CHEBURKIN, AND WILLIAM SHOTYK*
}

\section{FIGURE AND TABLES SUMMARY FOR SUPPORTING INFORMATION}

Figure S1. Third dimensional map of peat depth at Gola di Lago.

Figure S2. Spatial distribution of arsenic at GdL at the depths containing the maximum concentrations at site 8 and 9 , respectively.

Figure S3. XRD spectra of GdL $8(10-20 \mathrm{~cm})$ and GdL $9(220-230 \mathrm{~cm})$.

Figure S4. Scanning electron microphotograph of pyrite framboids in sample GdL 9 $(220-230 \mathrm{~cm})$.

Table S1. Sequential extraction procedure for arsenic (modified from [32,33]) 


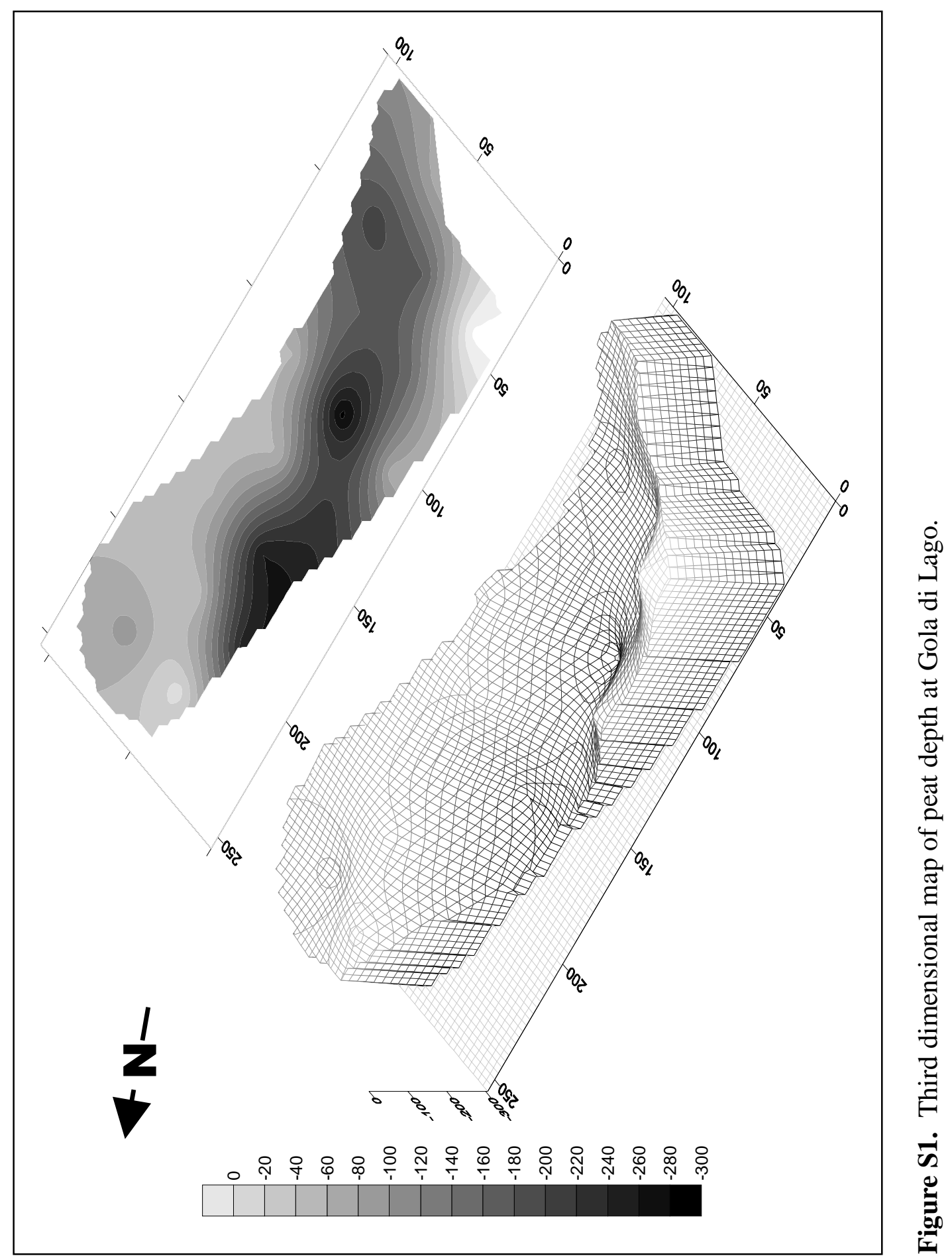




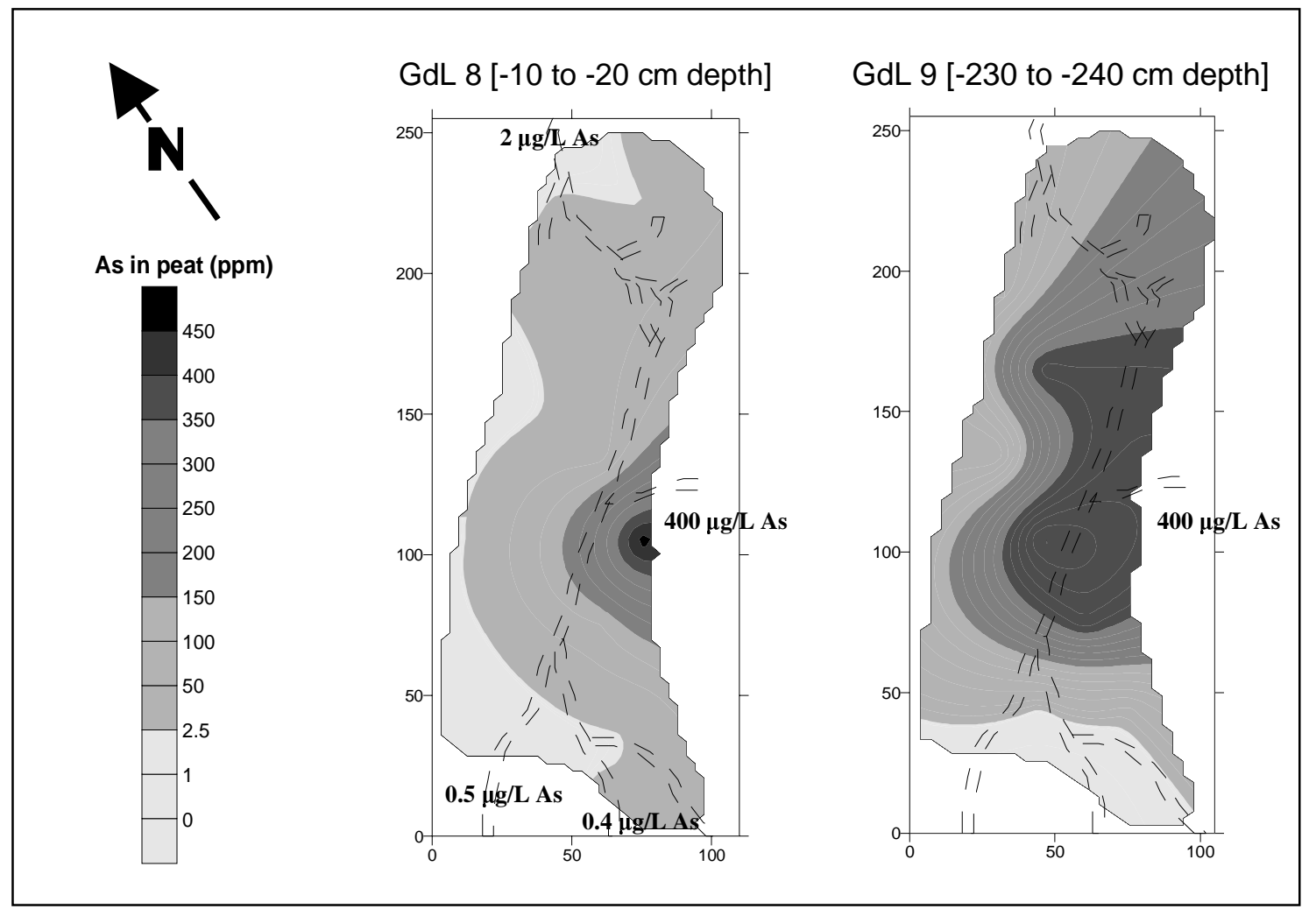

Figure S2. Spatial distribution of arsenic at GdL at the depths containing the maximum concentrations at site 8 and 9 , respectively. 


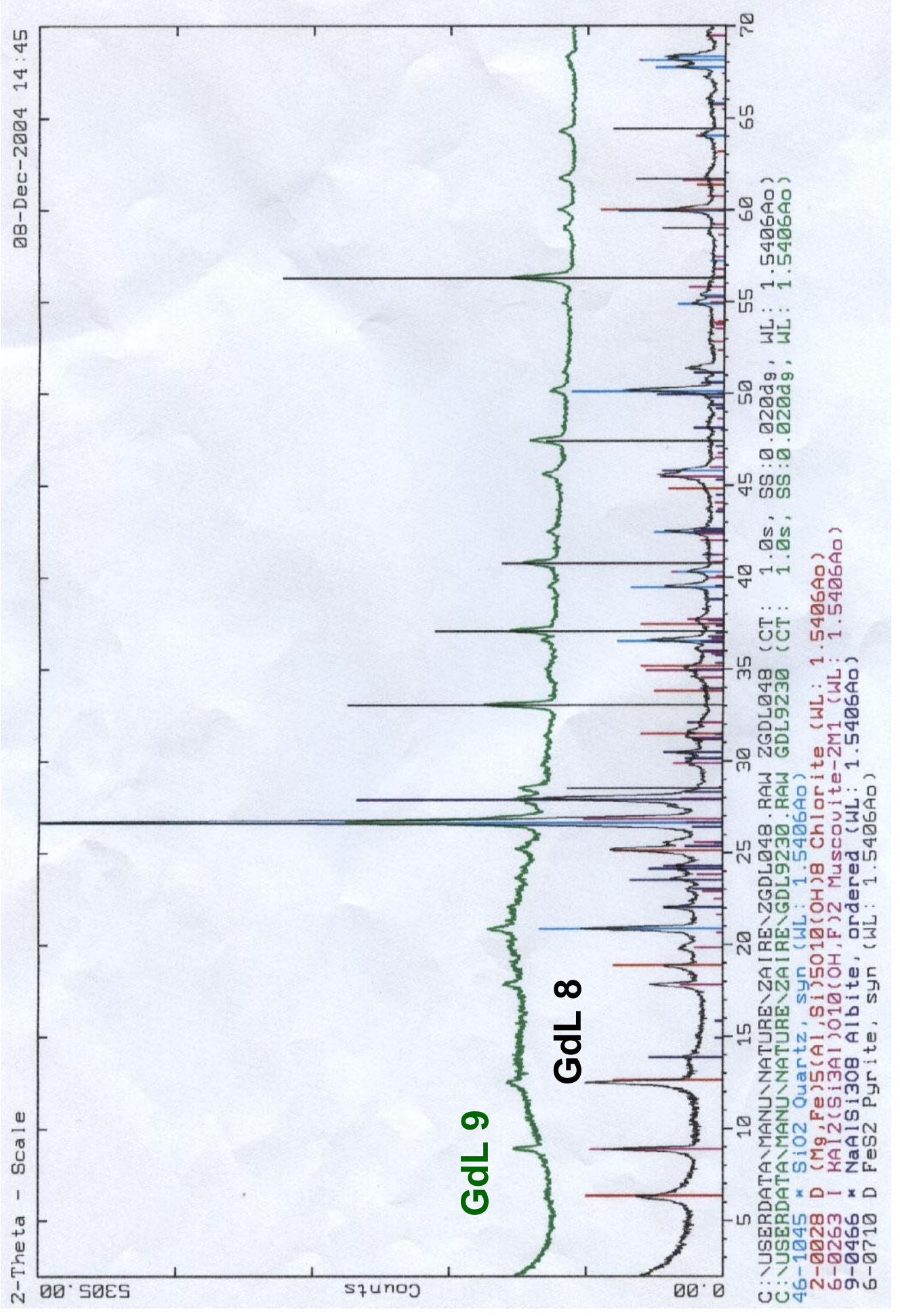




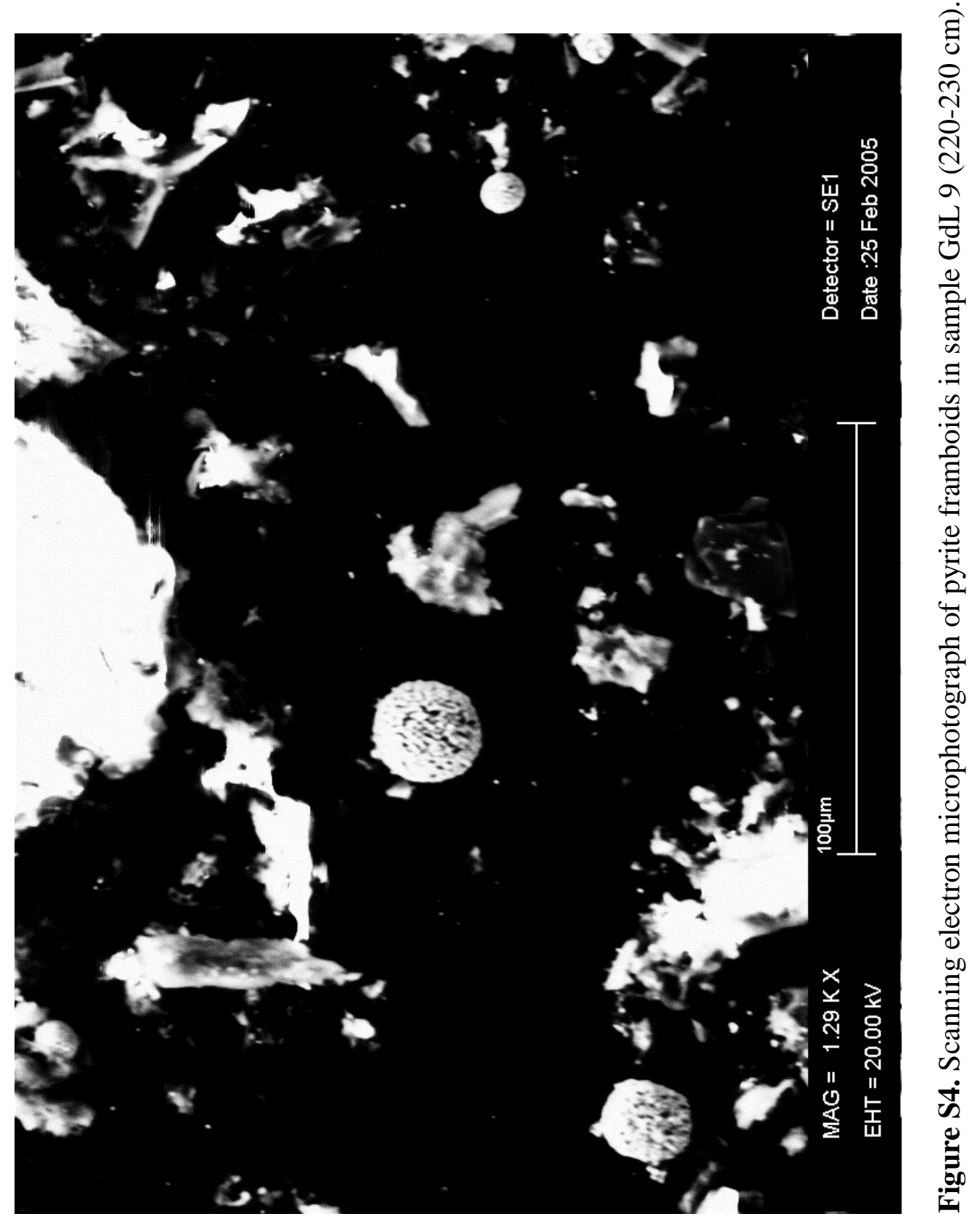


Table S1. Sequential extraction procedure for arsenic (modified from [32,33])

\begin{tabular}{|c|c|c|c|}
\hline Step & Reagent & Form & Reference \\
\hline 1 & $\begin{array}{l}1 \mathrm{M} \mathrm{NaH} \mathrm{PO}_{4}, \mathrm{pH} 5,24 \mathrm{hrs}, 25^{\circ} \mathrm{C} \text {, one } \\
\text { repetition. }\end{array}$ & $\begin{array}{l}\text { Strongly adsorbed As. } \\
\text { Anion exchange. }\end{array}$ & 32 \\
\hline w.w. & One water wash, $24 \mathrm{hrs}$. & & \\
\hline 2 & $1 \mathrm{~N} \mathrm{HCl}, 1 \mathrm{~h}, 25^{\circ} \mathrm{C}$, one repetition. & $\begin{array}{l}\text { As coprecipitated with } \\
\text { carbonates, Mn oxides, } \\
\text { and amorphous Fe }\end{array}$ & 32 \\
\hline w.w. & One water wash, $1 \mathrm{~h}$. & oxyhydroxides. & \\
\hline 3 & $\begin{array}{l}-3 \mathrm{ml} \text { of } 0.02 \mathrm{M} \mathrm{HNO}_{3} \text { and } 5 \mathrm{ml} \text { of } 30 \% \\
\mathrm{H}_{2} \mathrm{O}_{2} \text { with adjusted } \mathrm{pH} \text { of } 2 \text { with } \mathrm{HNO}_{3} \text {. } \\
\text { Heat the mixture to } 85 \pm 2{ }^{\circ} \mathrm{C} \text { for } 2 \mathrm{hrs} \text { with } \\
\text { occasional agitation. } \\
\text { - Add a second } 3 \mathrm{ml} \text { aliquot of } 30 \% \mathrm{H}_{2} \mathrm{O}_{2} \\
\left(\mathrm{pH} 2 \text { with } \mathrm{HNO}_{3} \text { ), heat again } 85 \pm 2{ }^{\circ} \mathrm{C} \text { for }\right. \\
3 \mathrm{hr} \text { with intermittent agitation. } \\
\text { - After cooling, } 5 \mathrm{ml} \text { of } 3.2 \mathrm{M} \mathrm{NH} \mathrm{OAc}_{4} \mathrm{OAn} \\
20 \% \text { (v/v) } \mathrm{HNO}_{3} \text { is added. } \\
\text { - The sample is diluted in } 20 \mathrm{ml} \text { and agitated } \\
\text { during } 30 \text { min. }\end{array}$ & $\begin{array}{l}\text { Bound to organic } \\
\text { matter. }\end{array}$ & 33 \\
\hline 5 & $\begin{array}{l}16 \mathrm{~N} \mathrm{HNO}_{3}+30 \% \mathrm{H}_{2} \mathrm{O}_{2} \text { (sand bath } \\
\text { digestion). }\end{array}$ & Residual. & 32 \\
\hline
\end{tabular}

* The reagents were added to each aliquot in sequential order, $0.4 \mathrm{~g}$ of peat sample were treated with $40 \mathrm{ml}$ of solution at every step. After the agitation time, the supernatant was separated at each step. The water wash was made with Milli-q water. The supernatants were measured for As with ICP-OES (LOD $1 \mu \mathrm{g} \mathrm{L}^{-1}$ ) and HG-AFS for concentrations below this LOD. 